\title{
Evaluating Cognitive Level of Final Semester Examination Questions Based on Bloom's Revised Taxonomy
}

\author{
Pirman Ginting 1, Yenni Hasnah², Selamat Husni Hasibuan 3, Ismail Hanif \\ Batubara4 \\ DOI: 10.35445/alishlah.v13i1.385
}

\section{Info Artikel}

Keywords: Bloom's revised taxonomy Cognitive level

Examination question Faculty courses

\begin{abstract}
This paper addresses the question of how cognitive levels covering high, middle, and low order thinking skills are delineated in the questions seen from Bloom's revised taxonomic framework and stimulus. To answer this question, the finalterm examination questions from five faculty courses were analyzed through document analysis. The documented examination questions are categorized and reviewed based on cognitive levels referring to revised Bloom's taxonomy. The questions are also construed based on the stimulus in each question. The results report that the cognitive level of tests is not wholly based on higher-order thinking skills. Of the five courses, only one follows the higher-order thinking skills-based question-writing system, and none of the items refers to middleorder thinking skills. Thus, the cognitive level on the test instruments has not led to an increase in thinking skills or is still at a low level of thinking.
\end{abstract}

Kata kunci:

Taksonomi Bloom

revisi

Tingkat kognitif

Soal ujian

Mata kuliah fakultas

\begin{abstract}
Abstrak
Penelitian ini membahas pertanyaan tentang bagaimana tingkat kognitif yang mencakup keterampilan berpikir tingkat tinggi, menengah, dan rendah direfleksikan pada pertanyaan, yang dilihat dari kerangka taksonomi Bloom yang direvisi dan stimulus. Untuk menjawab pertanyaan ini, pertanyaan ujian akhir semester dari lima program fakultas dianalisis melalui metode penelitian analisis dokumen (document analysis method). Soal ujian dikategorikan dan diresensi berdasarkan tingkat kognitif dengan mengacu pada taksonomi Bloom yang direvisi. Pertanyaan-pertanyaan tersebut juga ditafsirkan berdasarkan stimulus yang terdapat pada setiap pertanyaan. Hasil penelitian menunjukkan bahwa tingkat kognitif tes tidak sepenuhnya didasarkan pada keterampilan berpikir tingkat tinggi. Dari lima mata kuliah, hanya satu yang mengikuti kaidah penulisan pertanyaan berbasis keterampilan berpikir tingkat tinggi, dan tidak ada butir soal yang mengacu pada keterampilan berpikir tingkat menengah. Dengan demikian, tingkat kognitif pada instrumen tes secara keseluruhan belum mengarah pada
\end{abstract}

${ }^{1}$ Universitas Muhammadiyah Sumatera Utara, Medan, Indonesia

Email: pirmanginting@umsu.ac.id

2 Universitas Muhammadiyah Sumatera Utara, Medan, Indonesia

Email: yennihasnah@umsu.ac.id

3 Universitas Muhammadiyah Sumatera Utara, Medan, Indonesia

Email: selamathusni@umsu.ac.id

4 Universitas Muhammadiyah Sumatera Utara, Medan, Indonesia

Email: ismailhanif@umsu.ac.id

Vol.13 (1) June, 2021

Received: February 10, 2021; Received in revised form: March 3, 2021; Accepted: March 3, 2021; Available online: April 10, 2021

This is an open access article under a Creative Commons Attribution-NonCommercial-ShareAlike 4.0 International License 
peningkatan kemampuan berpikir atau masih berada pada tingkat berpikir rendah.

\section{PENDAHULUAN}

Pendidikan di era revolusi industri 4.0 diharapkan dapat menghasilkan peserta didik dengan keterampilan abad 21 yakni, berpikir kritis (Critical Thinking), kreatif (Creative), komunikasi (Communication) dan kolaborasi (Collaboration) yang dikenal dengan 4Cs (Risdianto, 2019). Peserta didik tidak hanya terampil dalam menjawab pertanyaan yang diberikan, tetapi juga harus memiliki kemampuan dalam memecahkan masalah, kemampuan berargumen, dan kemampuan mengambil keputusan serta cakap dalam mengambil keputusan. Peserta didik diharapkan dapat mengelola, mengolah dan merespon arus informasi dan pemutakhiran teknologi saat ini (Lutfianto \& Sari, 2017). Dengan kata lain, peserta didik mampu mengkategorikan benda, membandingkan dan mengkonstruksikan dengan teori, mempresentasikan masalah serta mengaplikasikan dalam kehidupan yang nyata (Sa’idah, Yulistianti \& Megawati, 2019). Oleh karena itu, perlu dilakukan usaha keras dalam merealisasikan tujuan tersebut.

Peningkatan kualitas pembelajaran berpikir kritis dapat dicapai melalui penerapan instrumen penilaian yang baik (Jusrianto, Zubair \& Megawati, 2018). Koksal \& Ulum (2018) menyatakan bahwa penilaian merupakan salah satu bagian yang sangat diperlukan dalam proses pembelajaran dalam rangka mengukur proses pembelajaran siswa. Salah satu bentuk pelaksanaan evaluasi penilaian adalah ujian akhir semester yang bertujuan untuk mengetahui tingkat kemajuan belajar peserta didik dan merupakan proses penilaian hasil belajar yang dilaksanakan peserta didik pada akhir semester (Rohman, 2015 \& Kurniawan, 2019). Ujian Akhir Semester (UAS) dilaksanakan setelah melakukan proses pembelajaran dalam kurun waktu tertentu sesuai dengan perencanaan yang telah disusun. Oleh karenanya, soal yang diujikan harus merujuk pada materi dan capaian pembelajaran yang telah disusun.

Dalam pembelajaran abad ke-21, rancangan penilaian harus disesuaikan dengan tingkat berpikir peserta didik sehingga evaluasi yang diterapkan dapat mencapai sasaran yang diinginkan. Instrumen penilaian (tes) yang dirancang hendaknya dapat merangsang dan melatih daya berfikir kritis peserta didik, yakni instrumen berbasis HOTS (High Order Thinking Skills). HOTS sebagai proses berpikir kritis dalam konteks pembelajaran adalah membentuk peserta didik yang mampu untuk berpikir logis (masuk akal), reflektif, dan mengambil keputusan secara mandiri. Soal HOTS mengukur dimensi metakognitif, tidak sekadar mengukur dimensi faktual, konseptual, atau prosedural saja. Dimensi metakognitif menggambarkan kemampuan menghubungkan beberapa konsep yang berbeda, menginterpretasikan, memecahkan masalah (problem solving), memilih strategi pemecahan masalah, menemukan metode baru, berargumen (reasoning), dan mengambil keputusan yang tepat. Soal yang termasuk Higher Order Thinking memiliki ciri-ciri: (a) transfer satu konsep ke konsep lainnya, (b) memproses dan menerapkan informasi, (c) mencari kaitan dari berbagai informasi yang berbeda-beda, (d) menggunakan informasi untuk menyelesaikan masalah, dan (e) menelaah ide dan informasi secara kritis (Setiawati, dkk., 2019). Davoudi \& Sadeghi, (2015) menegaskan bahwa penyajian pertanyaan yang mengandung High Order Thinking Skills mutlak diperlukan dalam mengembangkan kemampuan berpikir kritis peserta didik. Lebih lanjut, Peterson \& Taylor (2012) mengemukakan bahwa pertanyaan tingkat tinggi (higher order questioning) menuntut siswa untuk mampu berfikir lebih mendalam dan menguraikan tanggapan mereka secara lisan dan tertulis. Oleh sebab itu, dalam mendesain penilaian (evaluasi) perlu mempertimbangkan kebutuhan sehingga diperoleh hasil sesuai dengan capaian yang telah ditetapkan. Setiap jenis tes memiliki karakteristik tersendiri, baik dari segi bentuk soal, tingkat kesukaran, maupun cara pengolahan dan pendekatannya (Mania, 2012).

Penyusunan instrumen tentunya membutuhkan keahlian agar dapat menghasilkan suatu alat instrumen yang baik. Tidak jarang, dosen/guru sering kali mengalami tantangan dalam menulis 
soal, khususnya dalam menghasilkan pertanyaan yang berkualitas dan sedang (quality and fair questions) untuk mengukur tingkat berpikir yang berbeda (Abduljabbar \& Omar, 2015). Soal penilaian yang dihasilkan seringkali belum memenuhi kriteria yang sesuai dengan tuntutan keterampilan pembelajaran abad 21, dimana tes yang dihasilkan harus dapat mengembangkan daya berpikir peserta didik. Ahmad \& Sukiman (2019) dalam penelitiannya pada sebuah sekolah menunjukkan bahwa hanya sedikit soal yang memiliki karakterisitk HOTS, bahkan tidak ditemukan soal yang memuat C6 (mencipta). Secara kesuluruhan, soal didominasi bermuatan low order thinking skills ( 11 \& $\mathrm{C} 2$ ). Selain itu, rendahnya pemahaman terhadap tingkat taksonomi kognitif (berfikir) yang mengacu pada taksonomi bloom juga menjadi kendala serius bagi para pengajar untuk menghasilkan instrumen yang berkualitas, yang sesuai dengan tingkat berfikir (cognitive level) peserta didik. Penelitian oleh Ginting \& Kuswondo (2020) membuktikan bahwa pengetahuan dalam merancang tugas berbasis HOTS menjadi sebuah tantangan yang sulit bagi guru. Dari seluruh subjek penelitian, hampir 60\% memiliki kesulitan yang sama. Sementara itu, Ardini (2017), pada penelitiannya menyebutkan bahwa hanya $5 \%$ dari seluruh guru yang menjadi subjek penelitiannya memiliki pemahaman yang sangat baik tentang HOTS. Lebih lanjut, Motlhabane (2017) yang meneliti soal-soal ujian Fisika tahun terakhir 2014 dan 2015 di Afrika Selatan melaporkan bahwa tidak ada pertanyaan yang mengandung HOTS.

Sejalan dengan hasil penelitian di atas, hasil pengamatan awal (preliminary observation) yang dilakukan pada soal akhir semester genap tahun akademik 2019-2020 juga menunjukkan bahwa masih terdapat banyak soal tes yang tidak relevan dengan tingkat kognitif peserta didik (mahasiswa). Misalnya, soal yang diujikan kepada mahasiswa masih menggunakan level taksonomi C1 dan C2 seperti kata "sebutkan, tuliskan ciri-ciri, jelaskan perbedaan dan sebagainya". Akibatnya, tes tersebut tidak mampu memberikan hasil evaluasi yang baik terhadap level berpikir dan pemahaman peserta didik terhadap materi pembelajaran yang diajarkan. Hal ini tentunya juga sangat berdampak negatif terhadap kualitas kebijakan yang dihasilkan oleh guru/dosen dalam mengelola pembelajaran.

Oleh karena itu, penelitian ini penting dilakukan untuk menganalisis tingkat kognitif (LOTS, HOTS, dan MOTS) instrumen tes yang diujikan. Instrumen ini akan digunakan sebagai alat untuk mengukur tingkat penguasaan materi dan pengembangan daya berpikir kritis peserta didik. Hasil penelitian ini juga diharapkan dapat menjadi masukan dalam merancang butir soal berkualitas berbasis High Order Thinking Skills (HOTS) pada tes berikutnya, yang dapat merepresentasikan tingkat kemampuan siswa yang sesungguhnya.

\section{METODE}

Objek dari pada penelitian ini merupakan soal ujian akhir semester. Soal ujian diperoleh dari mata kuliah fakultas dimana dosen pengampu mata kuliah dan evaluasi soalnya ditetapkan oleh pimpinan fakultas. Pada penelitian ini, dokumen soal yang diuji merupakan soal ujian akhir semester akhir genap tahun akademik 2019-2020 dari lima mata kuliah fakultas. Soal ditulis dalam bentuk esai yang terdiri atas 24 butir soal. Dalam proses analisis data, penelitian ini mengadopsi metode penelitian analisis dokumen (document analysis method). Document analysis digunakan untuk mengevaluasi dan menginterpretasi data berupa dokumen cetak atau elektronik (Bowen, 2009; Smulowitz, 2017). Dokumen soal dikelompokkan dan direview berdasarkan level kognitif yang merujuk pada taksonomi Bloom revisi. Selain itu, penentuan kategori soal juga dianalisis berdasarkan stimulus yang dimuat pada setiap soal. Kemudian, setiap soal diintepretasikan untuk memberikan makna, memperoleh pemahaman dan pengembangan pengetahuan kritis terhadap analisis soal. Selanjutnya, data disajikan dalam bentuk deskripsi sehingga mudah untuk dipahami. Penyajian data dideskripsikan berdasarkan kategori tingkat berpikir (LOTS, MOTS, dan HOTS) yang disesuaikan dengan Taksonomi Anderson and Krathwohl (2001). Sementara itu, keabsahan data diperoleh melalui analisis sejawat (peer debriefing). Data yang diperoleh akan didiskusikan dalam 
Focus Group Discussion (FGD) dengan sejawat untuk menyamakan pandangan sehingga diperoleh hasil analisis data yang valid (Himmah, 2019).

\section{HASIL PENELITIAN DAN PEMBAHASAN}

Salah satu bentuk evaluasi yang dilakukan untuk mengukur tingkat keberhasilan suatu satuan pendidikan adalah tes. Arifin (2010) menjelaskan bahwa tes merupakan suatu teknik untuk melakukan evaluasi yang terdiri dari berbagai tugas yang harus diselesaikan oleh peserta didik dengan tujuan untuk memberi penilaian terhadap perilaku anak didik. Salah satu bentuk tes adalah tes ujian akhir semester. Tes ujian akhir semester dilaksanakan untuk mengukur tingkat penguasaan peserta didik terhadap materi yang diajarkan dalam satu semester. Tes ujian akhir semester mencakup materi dan Capaian Pembelajaran Mata Kuliah (CPMK) yang telah ditetapkan.

Pada kurikulum standar nasional pendidikan tinggi, penilaian pembelajaran merupakan satu apsek penting dalam pelaksanaan pembelajaran. Salah satu bentuk prinsip penilaian yang harus diterapkan adalah bersifat edukatif. Dengan kata lain, penilaian yang dilaksanakan harus mampu memberikan perbaikan terhadap perencanaan dan proses pembelajaran, sekaligus dapat membantu mencapai capaian pembelajaran lulusan yang telah ditetapkan (Kemendikbud, 2020). Penilaian akhir semester atau ujian akhir semester merupakan salah satu bentuk penilaian yang bertujuan untuk menguji tingkat penguasaan peserta didik terhadap materi yang disampaikan selama satu semester. Ujian akhir semester meliputi indikator yang mencakup kompetensi dasar yang telah ditentukan pada setiap semester. Pada tingkat perguruan tinggi, cakupan penilaian akhir semester meliputi capaian pembelajaran mata kuliah yang ditetapkan pada setiap semester.

Pada penelitian ini, bentuk ujian akhir semester yang diterapkan adalah dalam bentuk esai dan disesuaikan dengan materi dan capaian pembelajaran yang telah ditetapkan. Bila ditinjau dari perspektif Taksonomi Bloom, soal penilain akhir semester yang dirancang sebagian telah menggunakan level kognitif tingkat $\mathrm{C}_{4}, \mathrm{C}_{5}$ dan $\mathrm{C} 6$. Akan tetapi, disisi lain, soal-soal yang ada tidak dilengkapi dengan stimulus yang merupakan faktor penting dalam menghasilkan soal yang berbasis HOTS. Evaluasi soal ujian akhir semester yang dianalisis adalah soal dari mata kuliah fakultas (mata kuliah non-program studi) yang diajarkan pada semester genap tahun akademik 2019-2020, yang terdiri atas lima mata kuliah; Manajemen Pendidikan, Ibadah, Bimbingan Konseling, Statistik Pendidikan, dan Micro-Teaching. Bentuk soal yang diujikan adalah esai, dan setiap mata kuliah memiliki jumlah butir soal yang bervariasi, yakni antara 4-5 pertanyaan. Penyajian soal yang diujikan memperhatikan kajian materi dan capaian pembelajaran lulusan yang telah dirancang pada rencana program semester (RPS). Muatan materi yang diujikan pada soal akhir semester adalah materi yang telah diajarkan pada pertemuan setelah kegiatan pembelajaran mid-semester selesai. Ujian ini menjadi salah satu aspek penilaian, oleh karena itu, soal yang diujikan dapat mengukur kamampuan mahasiswa dengan baik dan objektif.

Ditinjau dari kriteria level kognitif, empat dari lima mata kuliah yang ditelaah masih menerapkan soal yang bersifat memahami (understanding) atau level $\mathrm{C}$, dan tidak didukung oleh stimulus (pengetahuan awal/suatu kasus tertentu) yang dapat mengarahkan peserta didik/mahasiswa untuk berfikir kritis dalam menjawab soal tersebut. Oleh karena itu, ketika ditinjau dari dimensi proses berpikir, maka instrumen tes yang diujikan pada kelima mata kuliah tersebut dapat dikategorikan ke dalam tiga tingkatan berpikir (cognitive level); Low Order Thinking Skill (LOTS), (Middle Order Thinking Skill (MOTS), dan High Order Thinking Skill (HOTS).

Pengkategorian soal ujian didasarkan pada tingkat proses berpikir yang merujuk pada taksonomi bloom revisi (Krathwohl, 2002) meliputi remembering (C1), understanding (C2), applying $\left(\mathrm{C}_{3}\right)$, analyzing $\left(\mathrm{C}_{4}\right)$, evaluating $\left(\mathrm{C}_{5}\right)$, dan creating (C6), dimana dimensi berpikir mengingat dan memahami dikelompokkan pada berpikir tingkat rendah (Low Order Thinking Skill), menerapkan dikategorikan sebagai berpikir tingkat menengah (Middle Order Thinking Skill), dan menganalisa, mengevaluasi dan mencipta diklasifikasikan kedalam berpikir tingkat tinggi (High 
Order Thinking Skill). Penyusunan instrumen sebaiknya memperhatikan penggunaan kata kerja operasional (KKO). Penggunaan kata kerja yang tepat akan menentukan tingkat kedalaman penguasaan materi yang akan dicapai. Dalam penyusunan soal, pemilihan kata kerja operasional dapat mengacu kepada kata kerja yang terdapat pada taksonomi bloom yang telah direvisi. Dalam konteks HOTS, soal harus dirancang dengan menerapkan kata kerja yang mencakup menganalisis (C4), mengevaluasi/menilai ( $\mathrm{C}_{5}$ ), dan menkreasi/mencipta (C6). Pengujian tes HOTS dapat melatih peserta didik untuk mengaktualisasikan atau mentransfer pengetahuan yang telah diajarkan pada konteks lain, memicu daya pikir kritis yang diwujudkan dalam bentuk kemampuan berpikir logis, melakukan refleksi/evaluasi dan menentukan solusi atas persoalan yang dihadapi secara mandiri (Brookhart, 2010). Soal-soal HOTS pada konteks evaluasi bertujuan untuk mengukur kecakapan dalam mentransfer satu konsep ke konsep lainnya, memproses dan mengiplementasikan informasi yang diperoleh, menghubungkan informasi yang bevariasi, menyelesaikan masalah melaui pemanfaatan informasi yang diperoleh, dan menganalisis gagasan dan informasi secara kritis (Kemendikbud, 2018).

Berdasarkan kategori tingkat proses berpikir di atas, data dalam penelitian ini tidak mewakili setiap level kognitif. Dari lima mata kuliah yang menjadi objek penelitian,terdapat satu mata kuliah dengan soal yang memenuhi kriteria HOTS, yakni mata kuliah Statistik seperti yang tersaji di bawah ini.

\section{Butir soal: \\ 1. Seorang guru yang bemama IDNAS secara tidak sengaja mencari tahu hubungan antara uang saku dengan nilai siswa. Dari pernyataan tersebut didapat variabel dependen $(\mathrm{Y})$ adalah nilai siswa dan variabel independen $(\mathrm{X})$ adalah Uang saku. Data-data yang didapat ditabulasikan sebagai berikut:}

\begin{tabular}{|c|c|c|c|c|c|}
\hline Uang saku & Nilai & Uang saku & Nilai & Uang saku & Nilai \\
\hline 2000 & 100 & 2500 & 100 & 3000 & 90 \\
\hline 3000 & 100 & 5000 & 100 & 9000 & 100 \\
\hline 3500 & 100 & 5000 & 60 & 8000 & 85 \\
\hline 2000 & 85 & 5000 & 60 & 3000 & 100 \\
\hline 1000 & 100 & 5000 & 90 & 3000 & 100 \\
\hline 4000 & 60 & 5000 & 85 & 2000 & 90 \\
\hline 5000 & 70 & 5000 & 100 & 8000 & 100 \\
\hline 10000 & 60 & 5000 & 60 & 2000 & 100 \\
\hline 4000 & 100 & 2000 & 100 & 5000 & 100 \\
\hline 4000 & 90 & 1000 & 70 & 5000 & 60 \\
\hline 4000 & 100 & 1000 & 100 & 10000 & 85 \\
\hline
\end{tabular}

Ditanya:

a. Tentukan persamaan regeresi linier sederhana

b. Tentukan uji kelinieritasan

c. Tentukan nilai koefisien korelasi

d. Tentukan nilai hipotesis

e. Tentukan nilai koefisien determinasi

\section{Gambar 1. Soal Ujian Statistik}

Pada soal statistik di atas terdapat lima butir pertanyaan. Apabila ditinjau dari dimensi proses bepikir berdasarkan taksonomi bloom revisi, maka seluruh butir soal tersebut termasuk kategori $\mathrm{C}_{3}$ (menerapkan), dimana peserta didik hanya diminta untuk menentukan satu bagian tertentu dari materi yang telah dipelajari. Akan tetapi, penyediaan isu pada awal soal sebagai stimulus mengindikasikan bahwa soal statistik di atas dapat digolongkan sebagai soal HOTS. Mahasiswa dituntut untuk dapat memahami informasi pada stimulus terlebih dahulu dan menganalisis keterkaitan antara informasi pada stimulus tersebut dengen perintah soal. Daya berpikir kritis 
mahasiswa sangat menentukan ketepatan dalam menggali dan menginterpretasi makna pernyataan pada stimulus yang diberikan. Kesalahan dalam menafsirkan makna informasi berpengaruh terhadap ketepatan dalam mejawab pertanyaan. Oleh karena itu, kemampuan mahasiswa dalam mengasosiasikan berbagai informasi yang ada menjadi fakor penting dalam menyelesaikan semua pertanyaan dengan baik. Proses analisis yang memerlukan daya pikir yang tajam untuk menjawab soal tersebut membuktikan bahwa KKO “tentukan” dapat diklasifikasikan ke dalam $\mathrm{C}_{5}$ (evalusi). Hal ini senada dengan pernyataan Kemendikbud (2019) bahwa untuk menghasilkan soal HOTS, hendaknya tidak hanya berfokus pada pemilihan KKO semata. Pemberian stimulus pada soal yang akan dapat merangsang proses berpikir kritis peserta didik merupakan faktor penting lainnya dalam menghasilkan soal HOTS. Kata kerja operasional 'menentukan' pada Taksonomi Bloom berada pada ranah berpikir tingkat $\mathrm{C}_{2}$ dan $\mathrm{C}_{3}$ dapat digolongkan pada kategori $\mathrm{C}_{5}$ (mengevaluasi) apabila soal tersebut didahului dengan stimulus yang mendorong proses berpikir peserta didik untuk melakukan analisis. Lebih jauh, kata kerja "menetukan" dapat digolongkan ke dalam dimensi berpikir C6 (menciptakan) jika pertanyaan berorientasi pada pemecahan masalah atau penentuan solusi. Oleh karena itu, variasi stimulus atau proses berpikir sangat berpengaruh terhadap penentuan kata kerja operasional dalam menjawab pertanyaan yang disajikan.

Selain itu, penggunaan stimulus yang kontekstual pada soal ini juga menjadi aspek penting untuk membantu merangsang mahasiswa dalam menerjemahkan maksud soal. Kata "guru" dan "uang saku" merupakan dua kata yang melekat erat dengan mahasiswa sehingga memudahkan mereka merefleksikan situasi yang disampaikan pada stimulus dan mengaitkannya dengan pertanyaan. Salah satu aturan penulisan soal HOTS adalah soal harus mengandung stimulus yang bersifat kontekstual dengan tujuan agar peserta didik dapat mengintegrasikan materi yang dipelajari di dalam kelas dengan realita di luar kelas. Bentuk soal seperti ini dapat menstimuli peserta didik untuk lebih aktif karena materi yang dipelajari berkaitan erat dengan kondisi nyata kehidupan mereka sehari-hari (Widana, 2020). Meskipun demikian, bahwa soal HOTS harus bersifat divergen, yakni soal disusun secara bervariasi tidak terlihat pada soal tersebut. Seluruh butir pertanyaan menggunakan kata kerja operasional yang sama, yakni 'tentukan'. Hal ini mengarahkan mahasiswa untuk memjawab setiap pertanyaan dengan pola dan proses berfikir yang relatif sama, bahkan peserta didik tidak dapat memproses jawaban dan menyajikannya secara kreatif sesuai dengan sudut padang mereka. Bentuk soal yang bervariasi memberikan peserta didik peluang untuk mengekplorasi kemampuan mereka dalam menjawab setiap soal sesuai dengan proses berpikir dan sudut pandang yang dimilikinya dengan analitis, kritis dan kreatif (Kemendikbud, 2019). Penggunaan bentuk soal yang beragam memudahkan guru atau dosen untuk menggali informasi tentang kemampuan peserta didik secara mendalam dan objektif (Fanani, 2013).

Soal HOTS juga ditemukan pada soal mata kuliah Menejemen Pendidikan. Terdapat lima butir soal yang diujikan pada mata kuliah tersebut, tiga diantaranya dikategorikan sebagai soal berkriteria HOTS, sementara itu, dua yang lain bersifat menghafal, seperti yang terlihat di bawah ini.

1. Jelaskan teknik-teknik supervisi?

2. Apakah pemimpin itu dilahirkan atau dibentuk? Jelaskan berdasarkan kajian teorinya?

3. Menurut Anda, bagaimana implementasi Teori Manajerial Grid di sekolah yang diobservasi?

4. Buatkan analisis SWOT sekolah yang diobervasi?

5. Apakah sekolah yang kita observasi termasuk sekolah bermutu? Jelaskan?

Gambar 2. Soal Manajemen Pendidikan 
Pada soal no. 4, mahasiswa diminta untuk menyusun sebuah analisis SWOT terhadap sebuah sekolah. Dari pertanyaan tersebut dapat dipahami secara jelas bahwa mahasiswa telah melakukan pengamatan terhadap sekolah tersebut untuk memperoleh berbagai informasi penting. Informasi yang diperoleh dianalisis dan dievaluasi. Hasil analisis dan evaluasi tersebut dijadikan sebagai referensi untuk menyusun analisis SWOT; kekuatan (strengths), kelemahan (weaknesses), kesempatan (opportunities) dan ancaman (threats). Pada konteks ini, soal dapat diklasifikasikan sebagai soal HOTS dengan kriteria C6 (menciptakan) karena mahasiswa tidak hanya dituntut untuk melakukan analisis dan evaluasi, tetapi juga harus dapat menghasilkan suatu analisis SWOT.

Karakteristik HOTS juga terdapat pada butir soal nomor 3 dan 5. Jika dipahami secara harfiah dan ditelisik mengunakan KKO, kedua butir soal termasuk dalam kategori C2 (menjelaskan) karena mahasiswa hanya dituntut untuk memberikan penjelasan. Tetapi, makna tersirat yang terkandung pada pertanyaan tersebut menegaskan bahwa jawaban yang dibutuhkan bukan berupa penjelasan yang dilandaskan pada pandangan mahasiswa itu sendiri. Misalnya, frase "yang kita observasi" pada soal nomor 5 menandakan bahwa penjelasan yang dikemukakan mengacu pada data yang diperoleh melalui pengamatan sebelumnya. Data tersebut menjadi stimulus bagi proses berfikir kritis mahasiswa dalam mengkaji dan mengukur mutu sekolah yang diamati, dan hasil kajian tersebut menjadi landasan dalam menjawab soal. Hasil analisis ini mengisyaratkan bahwa butir pertanyaan nomor 5 termasuk soal HOTS pada tingkat ranah kognitif $\mathrm{C}_{5}$ (evaluasi). Demikian juga halnya dengan soal nomor 3. Pada soal ini, mahasiswa ditugaskan untuk mengevaluasi atau menilai efektifitas penerapan teori manajerial Grid di sebuah sekolah yang telah diobservasi. Kualitas jawaban mahasiswa tentunya dipengaruhi oleh kemampuan mereka dalam memahami dan mengkritisi teori manejemen Grid dan melaksanakan refleksi terhadap implementasi teori tersebut. Oleh karenanya, kapabilitas mereka dalam mengasosiasikan makna teori Grid dengan manejemen yang diterapkan sekolah menjadi elemen penting. (Ruwaida, 2019) mengemukakan bahwa evaluasi merupakan kegiatan penilaian yang berdasar pada kriteria dan standar yang telah dirancang. Kriteria meliputi kualitas, efektivitas, efisien dan konsistensi. Standar bertujuan untuk mengukur kuantitas atau kualitas. Checking (mengecek) dan critiquing (mengkritik) adalah kategori menilai. Pada tingkat level berfikir $\mathrm{C}_{5}$ (evaluasi) peserta didik kompeten dalam menarik kesimpulan atas suatu keadaan atau gagasan, dan menghasilkan suatu ide dari keadaan atau padangan tersebut. Di sisi lain, butir soal 1 dan 2 tidak memiliki karakteristik HOTS. Kedua soal ini hanya mengarahkan mahasiswa untuk menjelaskan sebuah konsep melalui interpretasi teori yang telah dipelajari dan dipahami sebelumnya. Dalam menjawab soal, peserta didik tidak perlu melakukan proses analisis yang melibatkan informasi atau gagasan lain untuk menghasilkan suatu gagasan baru. Kategori tingkat berpikir yang diukur adalah memahami (C2) meskipun kata kerja operasional yang digunakan sama dengan tiga soal HOTS lainnya, yakni “menjelaskan'. Dengan kata lain, butir pertanyaan nomor 1 dan 2 termasuk kategori soal LOTS. Level kognitif C2 (memahami) meliputi kemampuan dalam mendefiniskan suatu pedoman dan menguatkan suatu gagasan yang telah dipelajari (Dinni, 2018).

Soal ujian akhir semester yang diujikan pada mata kuliah Bimbingan Konseling, Ibadah, Kemuhammadiyahan dan Micro-Teaching juga tidak mencirikan soal HOTS. Semua butir pertanyaan pada masing-masing mata kuliah hanya mengukur kemampuan berfikir tingkat rendah atau LOTS. Misalnya, soal pada mata kuliah Konseling yang terdiri atas lima butir hanya mengukur dimensi proses berfikir mengingat (C1) dan memahami (C2). Perintah soal adalah untuk menjelaskan dan menuliskan suatu materi spesifik yang telah dipelajari. Berikut adalah contoh soal mata kuliah Bimbingan Konseling yang diujikan pada ujian akhir semester. 


\section{Butir Soal:}

1. Jelaskan tolak ukur dalam mengetahui pemahaman peserta didik (20)

2. Sebutkan ciri-ciri model pembelajaran berbasis bimbingan (20)

3. Jelaskan peran dan fungsi BK dalam mengimplementasi kurikulum 2013 (30)

4. Jelaskan faktor-faktor penyebab kesulitan belajar peserta didik (30)

5. Tuliskan contoh observasi diagnostik kesulitan belajar (30)

\section{Gambar 3. Soal Ujian Bimbingan Konseling}

Seluruh soal tidak memiliki indikator untuk mengevaluasi proses berpikir tingkat tinggi. Soal juga tidak dilengkapi dengan stimulus berbasis permasalahan kontekstual yang dapat merangsang peserta didik melakukan analisis terhadap keterkaitan informasi pada permasalan kontekstual dan perintah soal untuk memperoleh jawab dalam bentuk gagasan baru dan kreatif. Butir soal nomor 2 dan 5 hanya menguji level befikir mengingat (C1). Deskripsi perintah kedua soal adalah mengingat materi sebelumnya (recall). Sementara itu, butir soal nomor 1, 3 dan 4 hanya membutuhkan jawaban berupa penjelasan, dengan tingkat proses berfikir C2 (memahami). Bentuk ketiga butir soal tersebut adalah menjelaskan konsep tertentu, dan tidak memiliki indikator untuk menakar keterampilan berargumentasi mahasiswa.

Pada mata kuliah Ibadah, pertanyaan yang dipergunakan juga masih pada tataran mengingat (C1) dan memahami (C2). Dua dari lima butir soal memiliki instruksi untuk menuliskan sebuah ungkapaa (do'a dan zikir) yang telah ada. Soal tidak dilengkapi dengan stimulus berupa kasus tertentu yang bersifat kontekstual untuk mendorong mahasiswa berfikir kritis dan kreatif dalam menghasilkan sebuah gagasan baru dalam bentuk tulisan. Sementara tiga soal lainnya hanya menguji pemahaman mahasiswa tentang materi pembelajaran tertentu. Mahasiswa hanya diperlukan untuk mendefinisikan material pembelajaran tersebut berdasarkan konsep yang ada dan telah dipelajari. Selanjtunya, butir pertanyaan pada mata kuliah Micro-Teaching juga tidak memiliki muatan kaidah HOTS. Terdapat 4 butir pertanyaan. Tiga diataranya hanya menguji kemampuan pemahaman mahasiswa tetang materi yang telah diajarkan. Selanjutnya, instruksi soal masih menggunakan kata kerja operasional pada ranah kognitf level C2 (memahami), dimana pada butir pertanyaan nomor 1 dan 4 mahasiswa hanya diminta untuk menguraikan (elaborate) definisi bagian materi tertentu, dan soal nomor 2 berbentuk deskripsi (describe) makna dari satu topik materi tertentu. Pada soal nomor 3, karakteristik pertanyaan bersifat mengingat (remembering). Bentuk kata perintah yang dimuat pada soal tersebut adalah menuliskan (write) komponen dari satu subbahasan materi. Pada tataran ini, soal hanya mengisyaratkan mahasiswa untuk menuliskan jawaban sesuai dengan teori yang telah dipelajari. Agar dapat menjawab soal ini, mahasiswa harus mampu mengingat kembali (recall) kajian materi yang telah dipelajari sebelumnya (Anderson \& Krathwohl, 2001). Semua soal tidak memuat stimulus sebagai pemacu untuk melatih kamampuan berargumentasi mahasiswa, serta tidak berbasis permasalahan kontekstual dan menarik (contextual and trending topic), yakni relating, experiencing, applying, communicating dan transferring. Sebaliknya, pertanyaan seharusnya merefleksikan tantangan/permasalahan yang dihadapkan pada dunia nyata sehingga mahasiswa berpeluang untuk mengasah kepiawaiannya dalam mengkronstruksi responsnya sendiri, dan mengembangkan gagasan dengan beragam jawaban benar yang didasarkan pada bukti, fakta dan/atau alasan rasional (Permendikbud 2019).

\section{SIMPULAN}

Level kognitif pada instrumen tes akhir semester yang diujikan secara keseluruhan belum mengarah ke peningkatan keterampilan berpikir kritis (critical thinking skills) mahasiswa. Hal ini terbukti dari tingkat berpikir (cognitive level) pada soal mata kuliah fakultas yang diujikan pada akhir semester belum berbasis HOTS secara keseluruhan. Merujuk pada hasil temuan ini, maka 
perlu dilakukan sosialisasi dan pelatihan lanjutan terkait pemutakhiran kurikulum terutama dalam kaitannya dengan perancangan kualitas evaluasi pembelajaran. Pelaksanaan pemutakhiran kurikulum terutama dalam kaitannya dengan kualitas evaluasi pembelajaran. Evauasi pembelajaran yang dirancang hendaknya dapat mengembangkan daya berpikir kritis dan kreativitas mahasiswa. Pemutakhiran evaluasi pembelajaran juga perlu disesuaikan dengan perkembangan ilmu pengetahuan dan realitas kehidupan yang relevan. Pengembangan pengetahuan dan keterampilan dosen dalam merancang evaluasi pembelajaran yang berkualitas juga perlu ditingkatkan. Upaya ini dapat dilakukan melalui pelatihan-pelatihan merancang soal berbasis HOTS yang dapat digunakan untuk mengukur dan mengembangkan berpikir kritis dan kreativitas mahasiswa.

\section{DAFTAR PUSTAKA}

Abduljabbar, D. A. \& Omar, N. (2015). Exam Questions Classification Based on Bloom's Taxonomy Cognitive Level Using Classifiers Combination. Journal of Theoretical and Applied Information Technology.

Ahmad \& Sukiman. (2019). Analisiss higher order thinking skills (hots) pada soal ujian akhir siswa kelas $6 \mathrm{kmi}$ dalam kelompok mata pelajaran dirasah islamiyah di pondok modern tazakka batang. Jurnal Pendidikan Agama Islam, 14(2): 137-164. DOI: https://doi.org/10.14421/jpai.2019.162-02

Anderson, L.W., \& Krathwohl, D.R. (2001). A Taxonomy for Learning, Teaching, and Assesing: A Revision of Bloom's Taxonomy of Educatioanl Objectives. New York: Addison Wesley Longman.

Ardini, S.N. (2017). Teachers' perception, knowledge and behaviour of higher order thinking skills (hots). Eternal: English Teaching Journal, 8(2). DOI: https://doi.org/10.26877/eternal.v8i2.3045

Arifin, Z.(2010). Makalah: Evaluasi Pembelajaran (Teori dan Praktik). Bandung: Universitas Pendidikan Indonesia, Fakultas Ilmu Pendidikan, Jurusan Kurikulum dan Teknologi Pendidikan.

Brookhart, S.M. (2010). How to Assess Higher-Order Thinking Skills in Your Classroom. United States of America: ASCD.

Davoudi, M. \& Sadeghi, N. A. (2015). A Systematic Review of Research on Questioning as a HighLevel Cognitive Strategy. English Language Teaching Vol. 8, No. 10; 2015. Doi: 10.5539/elt.v8n10p76.

Dinni, H. N. (2018). HOTS (High Order Thinking Skills) dan Kaitannya dengan Kemampuan Literasi Matematika. Makalah disajikan dalam Seminar Nasional Matematika, Universitas Negeri Semarang, 21 Oktober.

Fanani, M.Z. (2018). strategi pengembangan soal higher order thinking skill (hots) dalam kurikulum 2013. Edudeena: Journal of Islamic Religious Educatio, 2(1): 57-76. DOI: 10.30762/ed.v2i1.582

Ginting, A. A., \& Kuswondo, P. (2020). Challenge faced by english teachers: implementation of higher order thinking skills in designing assignment in east indonesia. Pedagogy Journal of English Language Teaching, 8(1). DOI: 10.32332/pedagogy.v8i1.1688

Himmah, W. I. (2019). Analisis soal penilaian akhir semester mata pelajaran matematika berdasarkan level berfikir. Journal of Medives, 3(1): 55-63. DOI: https://doi.org/10.31331/medivesveteran.v3i1.698

Jusrianto. Zahir, A., \& Megawati. (2018). Analisis kualitas tes ujian akhir semester mata kuliah pengetahuan komputer. Jurnal Studi Guru dan Pembelajaran, 1(1). DOI: https://doi.org/10.30605/jsgp.1.1.2018.7

Kemendikbud. (2018). Buku Penilaian Berorientasi Higher Order Thinkng Skills. Program Peningkatan Kompetensi Pembelajaran Berbasis Zonasi. Jakarta: Dirjen GTK Kementerian Pendidikan dan Kebudayaan 
Kemendikbud. (2019). Modul Penyusunan Soal Keterampilan Berfikir Tingkat Tinggi (Higher Order Thinking Skills) Bahasa dan Sastra Inggris. Jakarta: Direktorat Pembinaan Sekolah Menengah Atas, Ditjen Dikdasmen, Kemendikbud

Kemendikbud. (2019). Buku Penilaian Berorientasi Higher Order Thinking Skills. Program Pengembangan keprofesian Berkelanjutan (PKB) melalui Peningkatan Kompetensi Pembelajaran (PKP) Berbasis Zonasi. Jakarta: Dirjen GTK Kementerian Pendidikan dan Kebudayaan

Kemendikbud. 2020. Peraturan Menteri Pendidikan dan Kebudayaan Republik Indonesia Nomor 3 Tahun 2020 Tentang Standar Nasional Pendidikan Tinggi. Jakarta: Kemendikbud.

Koksal, D. \& Ulum, O. K. (2018). Language Assessment through Bloom's Taxonomy. Journal of Language and Linguistic Studies, 14(2), 76-88.

Krathwohl, D, R. (2002). Arevision of bloom's taxonomy: an overview. theory into practice. Autumn, 41 (4). https://doi.org/10.1207/s15430421tip4104_2

Kurniawan, D. D. (2019). Analisis butir soal ujian akhir semester matematika dengan teori respon butir. BRILIANT: Jurnal Riset dan Konseptual, 4(2). DOI: http://dx.doi.org/10.28926/briliant.v4i2.316

Lutfianto, M. \& Sari, A.F. (2017). Respon siswa terhadap soal matematika mirip pisa dengan konteks berintegrasi nilai islam. Jurnal Elemen, 3(2): 108-117. DOI: 10.29408/jel.v3i2.342

Mania, S. (2012). Pengantar Evaluasi Pengajaran. Makassar: Alauddin University Press.

Miles, M.B. \& Huberman A.M. (1994). Qualitative Data Analysis. California: SAGE Publications.

Motlhabane, A. (2017). Unpacking the south african physics examination questions according to bloom's revised taxonomy. Journal of Baltic Science Education, 16(6): 919-931. http://oaji.net/articles/2017/987-1513971062.pdf

Peterson, D. S. \& Taylor B. M. (2012). Using Higher Order Questioning to Accelerate Students' Growth in Reading. The Reading Teacher Vol. 65 Issue 5 February 2012, Doi: 10.1002/TRTR.01045.

Rohman.(2015). Pengembangan Instrumen Evaluasi Dan Penelitian. Purwokerto: STAIN Press.

Risdianto. (2019). Analisis Pendidikan Indonesia di Era revolusi Industri 4.o. Bengkulu: Universitas Bengkulu.

Ruwaida, H. (2019). Proses kognitif dalam taksonomi bloom revisi: analisis kemampuan mencipta (c6) pada pembelajaran fikih di mi miftahul anwar desa banua lawas. Al-Madrasah: Jurnal Ilmiah Pendidikan Madrasah Ibtidaiyah, 4(1):. DOI: http://dx.doi.org/10.35931/am.v4i1.168

Sa’idah, N., Yulistianti, H.D. \& Megawati, E. (2019). Analisis instrumen tes higher order thinking matematika smp. Jurnal Pendidikan Matematika, 13 (1). DOI: https://doi.org/10.22342/jpm.13.1.6619.41-54

Setiawati, W., dkk. (2019). Buku Penilaian Berorientasi High Order Thinking Skills.Jakarta: Direktorat Jenderal Guru dan Tenaga Kependidikan Kementerian Pendidikan dan Kebudayaan

Undang-Undang Nomor 20 Tahun 2003 tentang Sistem Pendidikan Nasional.

Widana, I Wayan.(2020). Kiat Jitu Menulis Soal Hots bagi Guru Matematika SMA/SMK. Lumajang: Mahameru Press. 